\title{
Activator-dependent regulation of transcriptional pausing on nucleosomal templates
}

\author{
Steven A. Brown, Anthony N. Imbalzano, and Robert E. Kingston ${ }^{1}$ \\ Department of Genetics, Harvard Medical School, and Department of Molecular Biology, Massachusetts General Hospital, \\ Boston, Massachusetts 02114 USA
}

\begin{abstract}
Promoter-proximal pausing during transcriptional elongation is an important way of regulating many diverse genes, including human c-myc and c-fos, some HIV genes, and the Drosophila heat shock loci. To characterize the mechanisms that regulate pausing, we have established an in vitro system using the human hsp 70 gene. We demonstrate that nucleosome formation increases by $>100$-fold the duration of a transcriptional pause on the human $h s p 70$ gene in vitro at the same location as pausing is observed in vivo. Readthrough of this pause is increased by an activator that contains the human heat shock factor 1 (HSF1) transcriptional activation domains. Maximal effect of the activator requires that the system be supplemented with fractions that have hSWI/SNF activity, which has been shown previously to alter nucleosome structure. No significant readthrough is observed in the absence of activator, and neither the activator nor the hSWI/SNF fraction affected elongation on naked DNA; therefore, these results suggest that an activator can cause increased readthrough of promoter-proximal pausing by decreasing the inhibitory effect of nucleosomes on transcriptional elongation.
\end{abstract}

[Key Words: Transcriptional pausing; nucleosomes; hsp70; heat shock factor 1; hSWl/SNF complex; transcriptional activators]

Received January 31, 1996; revised version accepted April 24, 1996.

Mechanisms of gene regulation at the level of transcriptional elongation have been well-characterized in prokaryotes. The identification of eukaryotic counterparts to these mechanisms is just beginning. Examples of regulated elongation in mammalian cells include the myc, myb, fos, mos, and ada genes, which exhibit a regulatory block to transcription near their 5 ' ends (for review, see Spencer and Groudine 1990). The Drosophila $h s p 70$ gene is also regulated at the level of elongation (Gilmour and Lis 1986; Rougvie and Lis 1988; Giardina et al. 1993). A paused, transcriptionally engaged RNA polymerase ternary complex has been found over a relatively narrow promoter-proximal region on $h s p 70$ (Rasmussen and Lis 1993). In response to heat shock, not only does the rate of initiation increase but the transit time of polymerase through the pause is drastically reduced. Similar pauses have been found in Drosophila on other heat shock genes (e.g., hsp26), metabolic genes (gadph-1 and gadph-2), and structural genes ( $\beta 1$-tubulin), so this phenomenon may be relatively widespread (Rougvie and Lis 1990).

What causes and what releases a eukaryotic pause remains mostly a mystery. Pausing on HIV-1 is at least

${ }^{1}$ Corresponding author. partially determined by an RNA-encoded TAR element and partially relieved by the Tat trans-activator (for review, see Cullen 1990). On human c-myc (Krumm et al. 1995) and Drosophila hsp70 (Lee et al. 1992) no such discrete elements have been found. Nonetheless, in vitro transcription studies on chromatin templates have shown that nucleosomes greatly enhance sequence-specific pausing (Izban and Luse 1991). This enhanced pausing might be a consequence of the need for nucleosomes to be displaced during the transcription process (Clark and Felsenfeld 1992; Studitsky et al. 1994). Hence, it is plausible that nucleosomes might play a role in the control of eukaryotic transcriptional elongation by causing specific, regulatable pauses. These pauses might then be regulated by transcriptional activators, by elongation factors like TFIIF (Flores et al. 1989) and TFIIS (Reinberg and Roeder 1987; Reines et al. 1989), or by chromatinreorganizing factors like the SWI/SNF complex /Winston and Carlson 1992; Cairns et al. 1994; Cote et al. 1994; Imbalzano et al. 1994; Kwon et al. 1994) or the Drosophila NURF complex (Tsukiyama and Wu 1995).

Activators have been implicated primarily in regulating transcriptional initiation on both naked and nucleosomal DNA, and current evidence suggests that they achieve their effects in several different ways. Direct contacts between activators and components of the gen- 
eral transcription machinery have been proposed to regulate pre-initiation complex formation and DNA melting at the promoter (for review, see Ptashne and Gann 1990; Kingston and Green 1994; Tjian and Maniatis 1994). Studies on chromatin templates show that activators can relieve nucleosomal inhibition of transcription, possibly through contacts with the general transcription machinery and with complexes like SWI/SNF that directly destabilize chromatin structure (for review, see Workman and Buchman 1993). Finally, activators may also play a direct role in the regulation of elongation. An in vivo study by Yankulov et al. (1994) demonstrated that a variety of activators are able to stimulate elongation through pausing and termination sites on stably transfected reporter constructs, and Krumm et al. (1995) found that enhancers can increase readthrough of promoter-proximal pausing.

This paper provides evidence that the human heat shock factor 1 (HSF1) transcriptional activation domains can regulate elongation through the human $h s p 70$ promoter in vitro and suggests that this is accomplished by overcoming a nucleosome-dependent block to transcriptional elongation. Specifically, we show that transcriptional pausing on $h s p 70$ is increased dramatically by the presence of nucleosomes. Pausing is released when reactions contain the HSFl activation domain as part of a GAL4 fusion protein, and maximal release also requires fractions with hSWI/SNF activity. Neither GAL4-HSF nor the hSWI/SNF fraction affect elongation on naked templates, suggesting that their effects on elongation are specific to the nucleosome-dependent block.

\section{Results}

A transcriptional pause is centered at +45 on the human hsp70 gene in vivo

Previous work has identified a regulated promoter-proximal transcriptional pause at several mammalian and Drosophila loci (for review, see Spencer and Groudine 1990). In particular, on the Drosophila hsp70 gene, paused polymerase molecules have been mapped in vivo by a variety of methods to between +20 and +30 relative to the start of transcription /Gilmour and Lis 1986; Rougvie and Lis 1988; Giardina et al. 1992; Rasmussen and Lis 1993). To understand how regulation of pausing might be achieved, we first determined whether the phenomenon of $h s p 70$ promoter-proximal pausing is conserved in humans (a result expected from the extraordinary conservation of the proteins involved among metazoans) and then established the human $h s p 70$ promoter as an in vitro system to examine the control of pausing. In this way we were able to compare pausing in our human cell-free system to pausing at the same locus in human cells.

To examine transcriptional pausing on the $h s p 70$ gene in vivo, potassium permanganate was used to footprint RNA polymerase open transcription complexes in HeLa cells. Permanganate freely diffuses through cell membranes and modifies thymine residues of single-stranded regions of DNA; hence, it is particularly useful for detecting regions of DNA in vivo that have been pulled apart by a paused, transcribing RNA polymerase molecule (Sasse-Dwight and Gralla 1989; Kainz and Roberts 1992; Wang et al. 1992). Modified bases can subsequently be changed to nicks by piperidine cleavage, and cleavage products can be examined by ligation-mediated PCR (LMPCR) (Mueller and Wold 1989). This permanganate footprinting protocol has been used previously to detect transcriptional pausing on the human c-myc and Drosophila hsp70 genes (Giardina et al. 1992; Krumm et al. 1992).

When growing HeLa cells were treated with permanganate, subsequent analysis of the cleavage products revealed a locus of coding-strand hypersensitivity centered at +45 compared with DNA treated with permanganate in vitro (Fig. 1A, lanes 1,2), which would not contain melted regions caused by RNA polymerase molecules. In contrast, there were only two minor hypersensitive sites at +30 and +48 on the noncoding strand (Fig. 1A, lanes $3,4)$. Such strand specificity is expected for footprints of transcriptionally engaged RNA polymerase molecules, because permanganate access to the noncoding strand is inhibited by the nascent transcript or by tight binding to RNA polymerase itself. Further evidence that the observed hypersensitivities were transcription-related was provided by permanganate footprinting studies done in the presence of the transcriptional inhibitors $\alpha$-amanitin or actinomycin-D. When HeLa cells were treated with either of these reagents prior to permanganate footprinting, the +45 hypersensitivity was reduced (Fig. 1B, lanes $3-6)$. Hence, it is likely that there is a paused, transcriptionally engaged RNA polymerase molecule at approximately +45 on the human $h s p 70$ gene in vivo.

When human cells are heat shocked, hsp 70 transcription increases $\sim 20$-fold (Morimoto 1993). Nonetheless, when heat-shocked HeLa cells were subjected to permanganate analysis, permanganate hypersensitivity in the human $h s p 70$ gene was similar to that seen in normally growing cells (Fig. 1C, lanes 1,2). This observation matches similar findings about the Drosophila hsp 70 gene (Giardina et al. 1992) and implies that RNA polymerase still pauses at this sequence following activation of the promoter; however, the pause must be less penetrant or shorter in duration to account for the increase in full-length transcript.

\section{Nucleosome-dependent pausing is observed on hsp 70 in vitro}

No long pauses are observed when naked $h s p 70$ DNA is transcribed by RNA polymerase II in vitro (see below). Because Izban and Luse (1991) had shown that nucleosomes can enhance sequence-specific pausing, we examined whether nucleosomes cause RNA polymerase II to pause at specific positions on the human $h s p 70$ promoter. We used a modification of the protocol of Izban and Luse to examine elongation of RNA polymerase at high nucleotide concentrations on nucleosomal templates. First, four point mutations were made in a tem- 

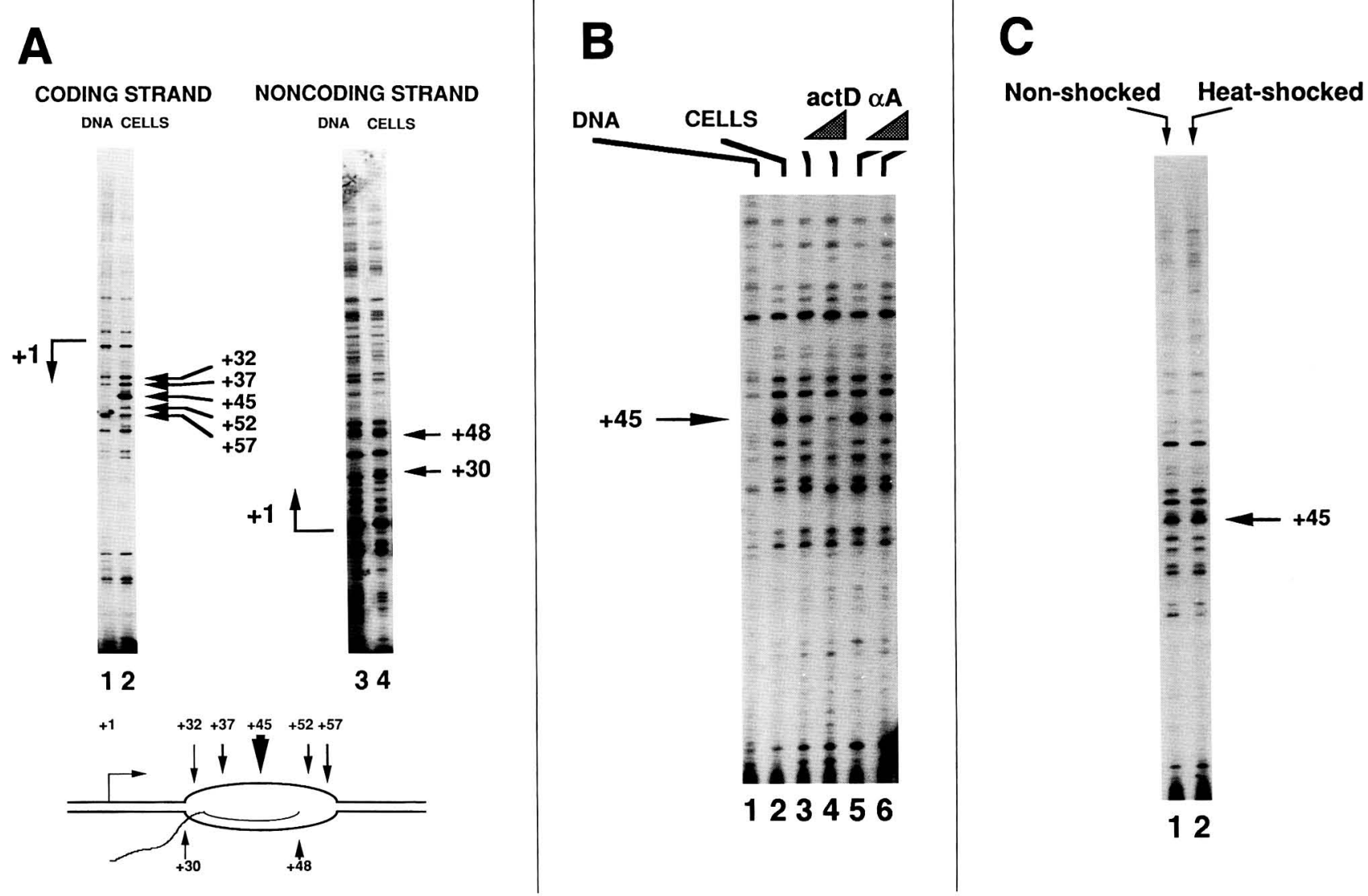

Figure 1. Permanganate hypersensitivity on the human $h s p 70$ gene in vivo. $(A)$ Intact HeLa cells (lanes 2,4$)$ or genomic DNA (lanes $1,3)$ were treated with potassium permanganate and coding strand cleavages (lanes 1,2$)$ or noncoding strand cleavages (lanes 3,4 ) were visualized by LMPCR. (B) HeLa cells were not treated (lane 2), or treated for $2 \mathrm{hr}$ with $1 \mu \mathrm{g} / \mathrm{ml}($ lane 3 ) or $5 \mu \mathrm{g} / \mathrm{ml}$ (lane 4) of actinomycin $\mathrm{D}$, or $1 \mu \mathrm{g} / \mathrm{ml}$ (lane 5 ) or $5 \mu \mathrm{g} / \mathrm{ml}$ (lane 6 ) of $\alpha$-amanitin, followed by potassium permanganate treatment and LMPCR to visualize coding-strand cleavages; genomic DNA (lane 1) is shown for comparison. $(C)$ HeLa cells were heat-shocked at $43^{\circ} \mathrm{C}$ for 1 hr (lane 2) or not heat-shocked (lane 1), and coding strand sensitivity to permanganate was visualized with LMPCR.

plate containing the natural human $h s p 70$ promoter so that there were no guanosine residues in the first 15 bases of the transcript. This modified hsp 70 template was tethered to polystyrene beads to facilitate changes of nucleotide mixes during transcription (Arias and Dynan 1989). Transcription was then initiated using HeLa basic transcription factors (partially purified to remove contaminating nucleotides), labeled UTP, and low concentrations of ATP and CTP. Under these "G-less" conditions, templates were generated that contain RNA polymerase artificially stalled at +15 with a labeled nascent transcript. Such prestalling of RNA polymerase complexes prior to nucleosome assembly was necessary to avoid the inhibitory effects of nucleosomes upon initiation (Knezetic and Luse 1986; Lorch et al. 1987; Matsui 1987 , so that we could specifically examine the effects of nucleosomes upon elongation.

After nucleotides and loosely bound proteins were washed away from the prestalled RNA polymerase II complexes with $1 \%$ Sarkosyl, nucleosomes or other factors were added as desired and transcription was permitted to continue by adding back high concentrations of all four unlabeled nucleotides. By performing a time course following the addition of nucleotides, the extent of pausing at specific positions in the $h s p 70$ gene could be determined directly by visualizing the end-labeled transcripts.

On naked $h s p 70$ DNA transcribed by this protocol, there was no evidence of a long-lasting specific pause (Fig. 2, lanes 1-3), but if the template was assembled into nucleosomes prior to the addition of nucleotides, RNA polymerase elongation was dramatically inhibited and almost all RNA polymerase molecules remained stopped at or before +46 to +49 (Fig. 2, lanes $4-6$ ), the location of pausing in vivo. Specifically, the major pause sites that we observed were at +46 to $+49(20 \%-50 \%$ of total counts over multiple experiments) and at +27 to +30 $(25 \%-50 \%)$. Quantitation of the latter pause is difficult because of its proximity to the dye front, and its significance is not currently known, as no pausing at this location was observed in vivo. Both of these pauses are stable for $>6 \mathrm{hr}$, the longest time point tested (data not shown).

The short transcripts that we observed could have 


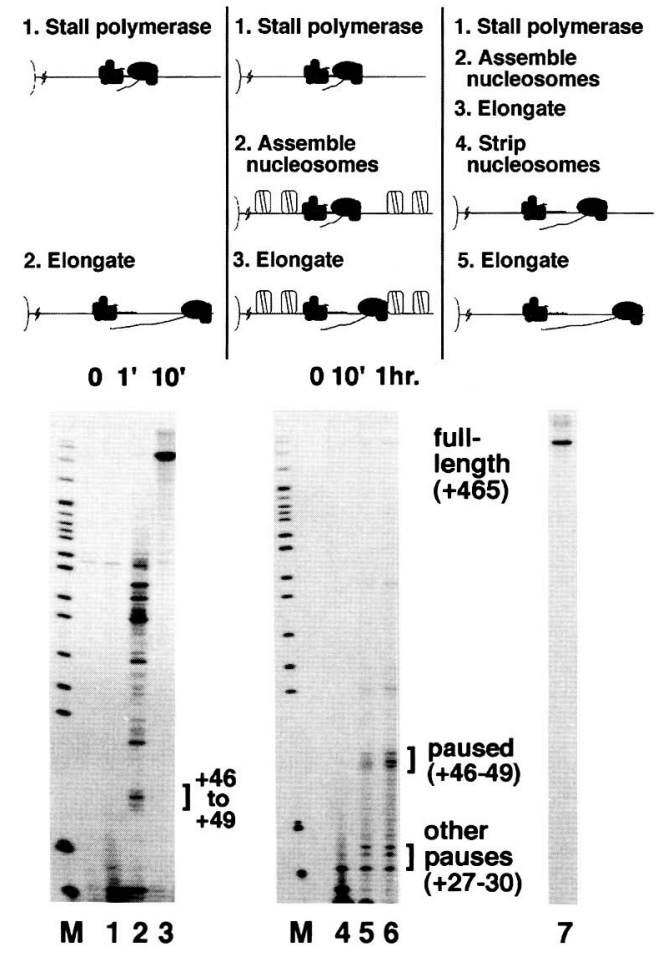

Figure 2. Transcriptional pausing on the human $h s p 70$ gene in vitro. Transcription complexes were stalled at +15 on human hsp70 template pSAB8 (containing a short G-less region from +1 to +15 ), washed, and either elongated immediately in the presence of all four unlabeled nucleotides (lanes 1-3) assembled into nucleosomes and then elongated (lanes 4-6), or assembled and elongated as in lane 6 , and then stripped of nucleosomes with a Sarkosyl wash and elongated again (lane 7); the period of elongation for each reaction is specified above lanes $1-6$, and was $1 \mathrm{hr}$ for lane 7.

been caused either by transcription termination or by pausing. To distinguish between these possibilities, nucleosomes were removed from reactions displaying the putative paused transcripts (e.g., lane 6) by washing with $1 \%$ Sarkosyl. Transcription was then permitted to continue by adding back all four nucleotides. At the end of this protocol, only full-length transcripts were observed (lane 7); hence, the paused transcripts in Figure 2 were the result of stably paused RNA polymerase that could elongate after removal of the nucleosomes and were not caused by premature termination.

\section{Promoter-proximal areas of the hsp70 transcribed region are nucleosomal in vitro and in vivo}

To further support this nucleosome-dependent model for hsp70 pausing, we next addressed whether templates that contained the paused polymerase were actually assembled into nucleosomes. Nucleosomal DNA is refractory to cleavage by restriction enzymes such as BamHI, so if nucleosomes were required for the pause at +46 to +49 , then these templates should not contain an acces- sible BamHI site at +150 . When stalled artificially, unassembled $h s p 70$ templates were cleaved with BamHI, the templates were cut at +150 , so subsequent elongation yielded nearly all short transcripts (Fig. 3A, lane 1). This control confirmed the accessibility of the BamHI restriction site in the absence of nucleosomes. When the templates were assembled into nucleosomes and then treated with $B a m H I$, almost all transcripts were paused at or before +46 to +49 , as discussed above (Fig. 3A, lane 2). A small fraction $(10 \%)$ reached the $B a m H I$ site at +150 , suggesting that they did not pause because they were unassembled. If these assembled and digested reactions were stripped of nucleosomes, all paused transcripts elongated to full-length transcripts (lane 3), whereas the backround of short, unassembled transcripts remained constant at $10 \%$. Therefore, all paused transcripts must have arisen from assembled templates. [This procedure was adapted from that described by Morse (1989).] The same experiment was conducted using restriction enzymes that cleave at various points along the template with similar results (Fig. 3B). Assembled templates were resistant to cleavage and gave fulllength transcripts upon removal of the nucleosomes (Fig. $3 B$, lanes $1,3,5,7)$. Unassembled templates were cut to give almost exclusively short transcripts (Fig. 3B, lanes $2,4,8$ ), with the exception of those treated with PstI, which also cleaves upstream of the start site thereby eliminating the transcript (Fig 3B, lane 6). From these experiments, it was concluded that all transcribed templates contain a nucleosome downstream of the start site.

We next examined whether the corresponding region of the $h s p 70$ gene is nucleosomal in vivo. When DNA from HeLa nuclei treated with micrococcal nuclease was transferred to nylon membrane and probed with a fragment of the $h s p 70$ gene stretching from +150 to +235 , a ladder of bands with the characteristic spacing of nucleosomes was observed (Fig. $3 \mathrm{C}$ ). This pattern was not observed on naked DNA, and no signal was observed on an identical blot of DNA from micrococcal nucleasetreated mouse nuclei (data not shown), implying that the observed pattern is not an artifact either of the intrinsic susceptibility of $h s p 70$ DNA to micrococcal nuclease cleavage or of hybridization specificity. We have not detected specific nucleosome positioning in this region as measured by indirect end-labeling (data not shown).

The pause observed on hsp70 in vitro is promoter-dependent

To demonstrate that the pattern of pausing that we measured in vitro was specific to the $h s p 70$ gene, we tested the adenovirus major late promoter in a similar in vitro assay. When this promoter instead of the $h s p 70$ promoter was transcribed with the protocol of Figure 2, inhibition of elongation and enhancement of sequence-specific pausing was observed (Izban and Luse 1991; Fig. 4A, lane 5 ), but there was no locus of sharply defined pausing at +46 to +49 like that on the hsp 70 gene (Fig. 4A, lane 1). 


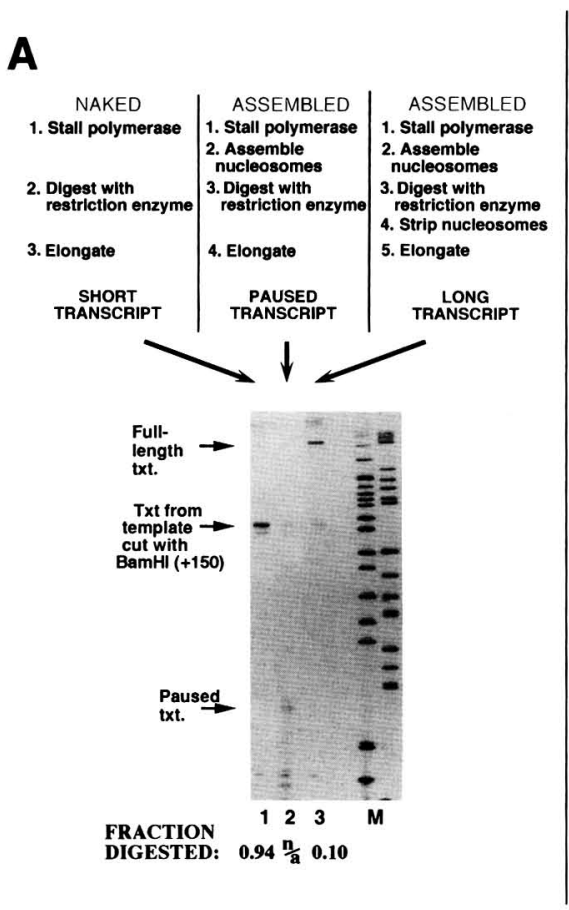

B

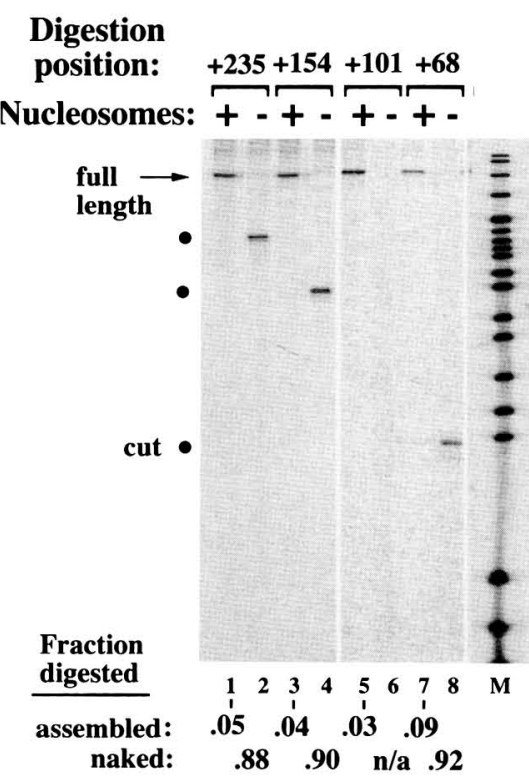

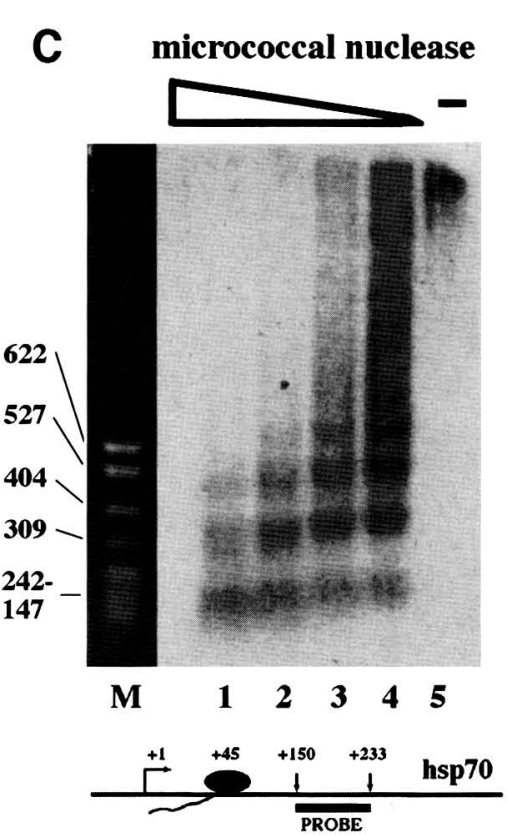

Figure 3. Nuclease accessibility of the $h s p 70$ gene in vitro and in vivo. (A) Naked templates with artificially stalled transcription complexes were either digested with BamHI and elongated (lane 1), assembled into nucleosomes and then digested with BamHI and elongated (lane 2), or assembled, digested, stripped of nucleosomes, and then elongated (lane 3). The ratio of short transcripts to full-length ones is quantitated underneath appropriate lanes. $(B)$ Restriction enzyme accessibility tests identical to the ones in $A$ were performed with SacII (lanes 1,2), BamHI (lanes 3,4). PstI (lanes 5,6), and StyI (lanes 7,8). Lanes 2, 4, 6, and 8 were digested as naked templates. Lanes 1, 3, 5, and 7 were digested after nucleosome assembly. Underneath each lane, the fraction of transcripts cut by restriction enzyme is indicated. (C) DNA from HeLa nuclei treated with 0 (lane 5), 30 (lane 4), 90 (lane 3), 270 (lane 2), or 810 (lane 1) units of micrococcal nuclease was Southern blotted and probed with a fragment of $h s p 70$ DNA from +150 to +235 . The marker lane contains pBR322 DNA digested with $M s p I$.

Hence, specific pausing at +46 to +49 was unique to the hsp70 gene.

Next, we carried out a variety of controls to address the possibility that the pause observed was of merely fortuitous length. We were concerned that the length of the linear template used in the protocol would cause nucleosomes to become positioned in a manner that would determine the location of the pause site. We found, however, that the pausing observed on hsp70 in vitro was independent of template length: The same +46 to +49 pause was observed on a mixture of templates containing from 335 to $395 \mathrm{bp}$ of downstream sequence (Fig. 4A, lane 3). Next, the independence of +46 to +49 pausing from the location of initial artificial stalling at +15 was demonstrated by examining pausing while varying the location of the artificial stall. We obtained the same results if RNA polymerase was stalled at +1 prior to nucleosome assembly (by initially withholding nucleotides entirely), as we did if we permitted RNA polymerase to progress to +15 prior to assembly (by adding three nucleotides) (Fig. 4B). Taken together, these experiments show that the specific nucleosome-dependent pausing that we observe on $h s p 70$ in vitro arises from some quality intrinsic to the $h s p 70$ gene rather than from some aspect of our in vitro system.

\section{Activator-dependent release of pausing}

Activation of the human hsp70 gene following heat shock is caused by the binding of an activated form of human HSF1 to the heat shock element. The transcriptional activation domains of human HSFl, amino acids 202-529 (Green et al. 1995; Zuo et al. 1995), were therefore tested for their ability to relieve pausing on the hsp70 gene in vitro. We used a GAL4 DNA binding domain to tether the HSF1 activation domains to the promoter region because the magnesium and detergent requirements for DNA binding by intact HSF1 purified from human cells (Schuetz et al. 1991) are incompatible with the experimental protocol used here.

When GAL4-HSF was prebound to an hsp70 promoter containing five GAL4 DNA-binding sites, there was some increased readthrough of the +46 to +49 pause (Fig. 5A, cf. lanes 1 and 2). Because GAL4-HSF addition alone did not promote a large amount of readthrough, a search for accessory factors was undertaken. One possible class of accessory factors are elongation factors known to relieve pausing in other in vitro systems, such as TFIIF (Flores et al. 1989) and TFIIS (Reinberg and Roeder 1987; Reines et al. 1989). Alone or in the presence of GAL4-HSF, though, these two factors had no 
A

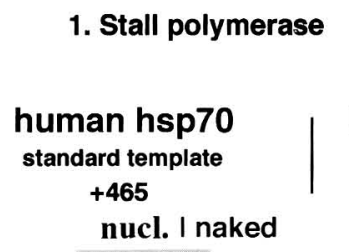
2. Assemble nucleosomes WITH human hsp70 varying $3^{\prime}$ length $+335-395$ nucl. I naked nucl. I naked
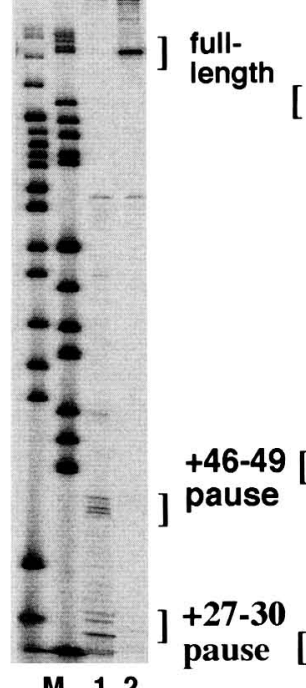

0.05

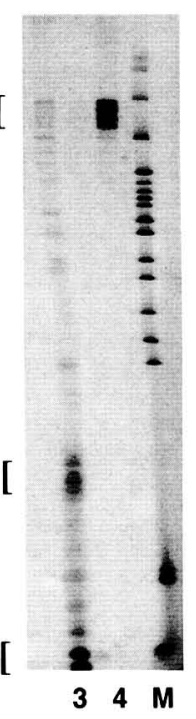

0.1

\section{Elongate}

adenovirus MLP

nucl. I naked

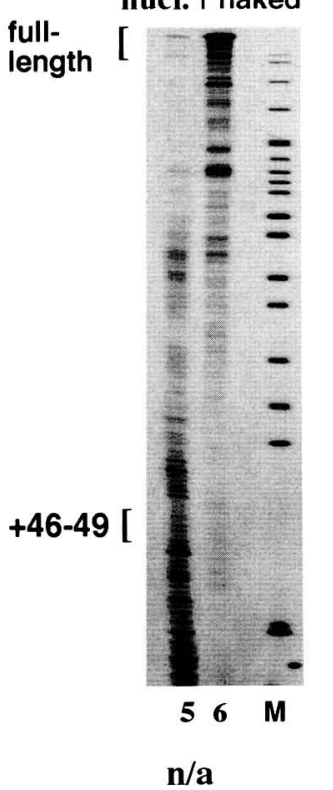

B \begin{tabular}{l|l}
$\begin{array}{c}\text { 1. Stall polymerase } \\
\text { at }+15\end{array}$ & $\begin{array}{c}1 \text { Stall polymerase } \\
\text { at }+1\end{array}$
\end{tabular}

2. Assemble nucleosomes 3. Elongate

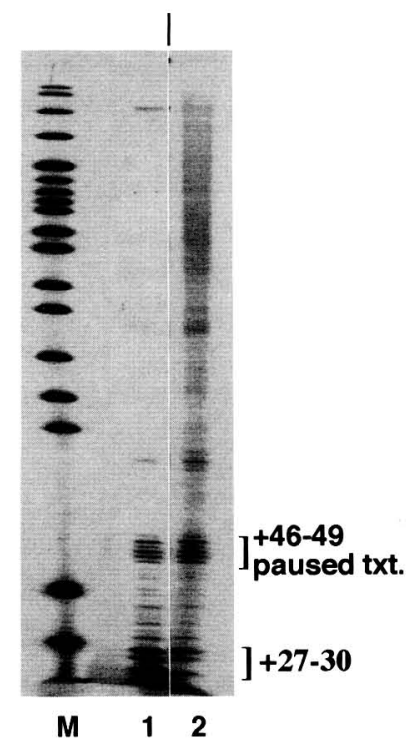

full-length/46-49: $\quad 0.10 .05$

Figure 4. The in vitro pause is promoter-dependent but independent from template length and the location of initial artificial stalling. (A) Pausing of RNA polymerase on various templates: pSAB8, human $h s p 70$ to +465 , nucleosomal (lane 1) or naked (lane 2); pSABmix, human $h s p 70$ to $+335,+355,+375,+395$, nucleosomal (lane 3) or naked (lane 4); pML5-4NR, adenvirus major late promoter (MLP) with 637 bp downstream sequence, nucleosomal (lane 5) or naked (lane 6). In all cases, elongation was permitted to occur for $1 \mathrm{hr}$. The ratio of full-length transcript to +46 to +49 paused transcripts is listed for nucleosomal DNA below each relevant lane. The ratio of +46 to +49 transcript to +27 to +30 transcript was 0.9 in lane 1 and 0.3 in lane 3 . $(B)$ Transcription complexes were initially stalled at +1 by withholding all nucleotides (lane 2 ) or at +15 by supplying three nucleotides (lane 1 ), followed by subsequent nucleosome assembly and elongation in the presence of all four nucleotides. The ratio of full-length transcripts to +46 to +49 transcripts is listed below each lane. The ratio of +46 to +49 to +27 to +30 transcripts was 0.5 in lane 1 and 0.9 in lane 2 . Because transcription complexes stalled at +1 were stalled as preinitiation complexes rather than elongation complexes, the Sarkosyl washing step prior to nucleosome assembly, which would strip these preinitiation complexes, had to be omitted from the standard protocol. The lack of Sarkosyl washing accounts for the increased background in lane 2 and in other unwashed reactions containing elongation complexes (data not shown).

effect upon the exent of readthrough of pausing /data not shown).

Because the pause at +46 to +49 was nucleosome dependent, we next investigated whether fractions containing hSWI/SNF activity could effect release of the pause. The yeast SWI/SNF complex has been implicated by genetic and biochemical studies to be involved in chromatin reorganization and gene activation (for review, see Winston and Carlson 1992), and the purified complex has been shown to possess an ATP-dependent nucleosome-disrupting activity (Cote et al. 1994). Fractions enriched for homologous complexes from HeLa cells display similar ATP-dependent reorganizing abilities (Imbalzano et al. 1994; Kwon et al. 1994). We therefore tested fractions that contain human SWI/SNF activity to see whether they would enhance relief of pausing on the $h s p 70$ gene. Readthrough was greatly enhanced by the presence of either the human SWI/SNF A fraction (Fig. 5A, lane 4) or the SWI/SNF B fraction (data not shown), two highly enriched, chromatographically distinct fractions that both contain human homologs of the yeast SWI2/SNF2 protein (Imbalzano et al. 1994; Kwon et al. 1994). At the same time, the amount of paused transcript decreased correspondingly (see legend to Fig. 5). These fractions had no effect upon readthrough when an ATP analog with a nonhydrolyzable $\gamma$ phosphate was employed during the reaction (ATP $\gamma$ S, data not shown). Interestingly, the same fractions also had no effect on pausing in the absence of activator (Fig. 5A, lane 3; see below). Hence, the actions of both an activator and an ATP-dependent activity were required for maximal relief of nucleosome-dependent pausing.

Because readthrough of pausing required the GAL4 HSF protein regardless of any accessory factors present, 
A

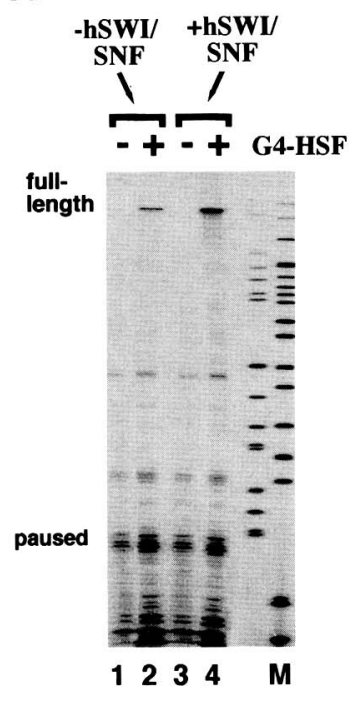

B

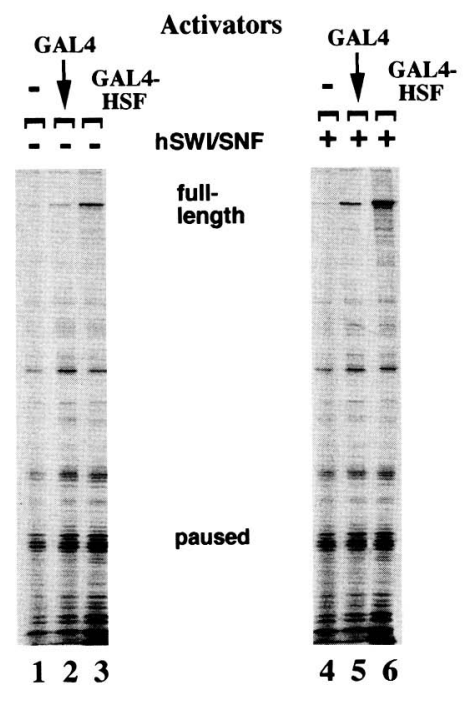

Figure 5. Effects of HSFl activation domain and the hSWI/SNF fraction upon pausing. (A) Template pSAB 12 (a hsp 70 transcription template similar to the one used in Figures 2-3, but containing 5 GAL4 DNAbinding sites/ was subjected to the standard elongation protocol of artificially stalling RNA polymerase complexes at +15 , assembling nucleosomes, and continuing elongation. (Lanes 3,4) 1 unit of hSWI/SNF preincubated in the presence of $4 \mathrm{~mm}$ ATP $15 \mathrm{~min}$ prior to the final elongation step of the reactions. (Lanes 2,4) A 1.2-fold molar excess of GAL4-HSF over binding sites preincubated with naked template for $15 \mathrm{~min}$, and then present during all steps of the transcription. (Lane 1) Neither activator nor hSWI/SNF. Between lanes 2 and 4 , the +46 to +49 transcript decreases from 183 to 153 units, and smaller transcripts decrease from 292 units to 242 units, for a total decrease of 80 units. At the same time, the full-length transcripts increase from 32 units to 107 units, for a total increase of 75 units. The units here are arbitrary light units as quantified by a Molecular Dynamics PhosphorImager. $(B)$ Standard elongation assays (as in $A$ ) were carried out upon pSAB12. No activator (lanes 1,4), the GAL4 DNA-binding domain (amino acids 1-94; lanes 2,5), or

the GAL4-HSF fusion protein (lanes 3,6) was preincubated (at 1.2-fold molar excess over sites) with template for 15 min, and remained present throughout the transcription. In lanes 4-6, one unit of the hSWI/SNF fraction was preincubated with assembled templates in the presence of $4 \mathrm{mM}$ ATP, and remained present during the final elongation step. The hSWI/SNF fraction was absent from lanes 1-3. These experiments are quantitated in Fig. 6.

we next addressed whether the HSF activation domain itself was necessary for this relief. To do this, we tested the GAL4 DNA-binding domain alone (amino acids 1-94 of the GAL4 protein) to see whether it could promote a similar effect in the presence or in the absence of the hSWI/SNF fractions (Fig. 5B). Under both conditions, maximal readthrough of the pause required the HSF activation domains (cf. lanes 2 and 5 with lanes 3 and 6). Data from these and other experiments were quantified by determining the ratio (full length transcript $/ / /+46$ to +49 paused transcript + full length transcript) using a PhosphorImager, and this ratio was plotted at different concentrations of hSWI/SNF in the reaction (Fig. 6). There was no significant effect of hSWI/SNF fractions on readthrough in the absence of an activator at any concentration. Maximal effects on readthrough required both GAL4-HSF and the hSWI/SNF fraction; under these conditions, readthrough increased 10 -fold over that seen without activator. GAL4(1-94) had a slight effect on readthrough that was significantly lower than the effect of GAL4-HSF. This small effect is consistent with the previously documented ability of GAL4(1-94) to stimulate transcription weakly on nucleosomal templates (Workman et al. 1991b; Croston et al. 1992). We conclude that GAL4-HSF can increase readthrough of a nucleosome-dependent pause in this in vitro system.

\section{GAL4-HSF and hSWI/SNF fractions do not affect pausing on naked DNA templates}

The effect of GAL4-HSF on pausing on the nucleosomal template might reflect a general ability of this activator to effect elongation or might be specific to regulation of elongation on nucleosomal templates. We examined elongation of transcription on the naked $h s p 70$ template and detected several positions where RNA polymerase pauses transiently, including a pause at +46 to +49 that had a half-life of $\sim 3 \mathrm{~min}$ (Fig. 7). We found no effect of GAL4-HSF or hSWI/SNF fractions on the extent of pausing on the naked $h s p 70$ promoter and conclude that the effects we observe upon pausing are specific to nucleosomal templates.

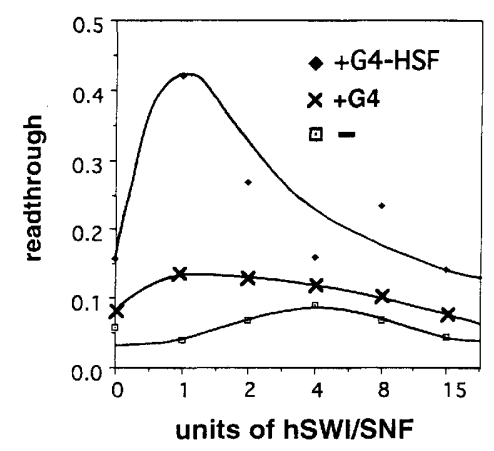

Figure 6. The effects of GAL4-HSF and the GAL4 DNA-binding domain are graphed as a function of the amount of hSWI/ SNF present in the reaction. Transcriptional assays were performed exactly as in Fig. 4 but with the amount of hSWI/SNF indicated along the $x$-axis present during the final elongation step. Readthrough was quantitated as follows: (amount of +465 transcript $/ /$ (amount of +465 transcript + amount of +46 to +49 transcript). The data shown are from a single typical titration; the trends observed were verified in several other such titrations. 


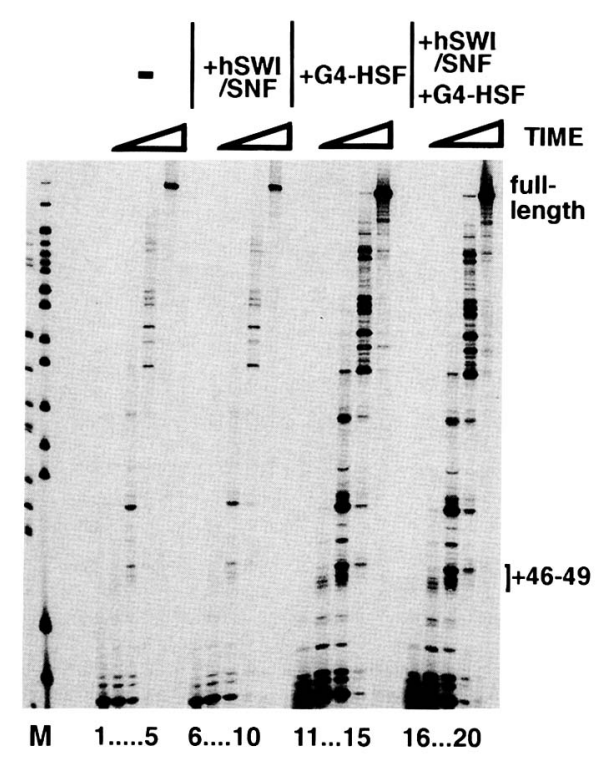

Figure 7. Effects of GAL4-HSF and hSWI/SNF upon pausing on naked DNA templates. Transcription complexes were artificially stalled at +15 on pSAB 12 templates by adding only ATP, CTP, and labeled UTP. After washing, the complexes were elongated by adding all four unlabeled nucleotides and incubating for 0 min (lanes 1,6,11,16), 1 min (lanes 2,7,12,17), $3 \mathrm{~min}$ (lanes $3,8,13,18$ ), 10 min (lanes $4,9,14,19$ ), or 30 min (lanes $5,10,15,20$ ). In lanes 11-20, GAL4-HSF was preincubated at a 1.2 -fold molar excess over binding sites/ with templates for 15 min prior to the start of transcription reactions, and remained present throughout the reactions. In lanes 6-10 and 16-20, 1 unit of the hSWI/SNF fraction was incubated with artificially stalled templates in the presence of $4 \mathrm{mM}$ ATP for $15 \mathrm{~min}$ prior to the addition of all four nucleotides, and remained present throughout the elongation.

\section{Discussion}

The primary conclusions from this work are that nucleosome formation greatly enhances a transcriptional pause on the human $h s p 70$ gene (Figs. 2 and 4 ) in vitro and that the HSF1 transcriptional activation domain can relieve this pause (Fig. 5). The effect of the activation domain on pausing is seen only on a nucleosomal template; therefore, our data imply that a novel and important aspect of activation domain function is to decrease the inhibitory effect of nucleosomes on elongation of RNA polymerase. Previous studies have demonstrated that total transcription is stimulated to a significantly greater extent by activation domains on nucleosomal templates as compared to naked templates (Workman et al. 1991b; Croston et al. 1992). This difference has been attributed to an ability of activation domains to alleviate a nucleosome-dependent inhibition of pre-initiation complex formation (for review, see Workman and Buchman 1993). The ability of activation domains characterized here to alleviate nucleosome-dependent inhibition of elongation complements this work.

\section{Nucleosomes affect pausing on the human hsp70 gene}

It has been appreciated for some time that there are sig- nificant steric problems to be overcome during elongation of RNA polymerase through a nucleosome. RNA polymerase II has been shown to transcribe through nucleosomal DNA in vitro (Lorch et al. 1987; for review, see van Holde et al. 1992); however, studies with SP6 polymerase suggest that the nucleosome is displaced in a process that appears to involve direct transfer to different DNA sequences on the same template (Clark and Felsenfeld 1992; Studitsky et al. 1994). From these data, it seemed reasonable that nucleosomes might inhibit the rate of transcriptional elongation, and nucleosome formation has been shown to increase pausing of RNA polymerase II in vitro (Izban and Luse 1991).

We show here that nucleosome formation has a particularly dramatic effect on formation of a paused polymerase at nucleotides +27 and +46 of the human $h s p 70$ transcribed region. There is a pause that lasts $\sim 3 \mathrm{~min}$ at the latter site on naked DNA (Fig. 7). On nucleosomal templates, these pauses last for $\geqslant 6 \mathrm{hr}$ (the longest timepoint we have examined), so the duration of pausing is increased $\geqslant 100$-fold by formation of the template into nucleosomes. We have used permanganate footprinting to show that one of these pauses is similar to one in vivo (Fig. 1). This region of the human $h s p 70$ template is nucleosomal in vivo (Fig. 3), consistent with the hypothesis that nucleosomes might contribute to formation of this pause, in vivo as well as in vitro. Such nucleosomes need not even be positioned precisely to facilitate specific pausing. Izban and Luse (1991) and O'Neill et al. (1992) have found that nucleosomes greatly enhance intrinsic DNA pausing sites. Studitsky et al. (1995) have reached similar conclusions, although they believe that this enhancement is confined to a particular region of the nucleosomal core. Our data concerning enhancement of the +46 to +49 pause is consistent with this previous work. Furthermore, pausing on the $h s p 70$ gene is conserved between humans and Drosophila, and promoter-proximal pauses are seen on several other mammalian and Drosophila genes (Rougvie and Lis 1988; Spencer and Groudine 1990). This fact raises the possibility that the observations we have made here concerning the role of nucleosomes on inducing pauses might be more general.

\section{Relief of pausing by activation domains}

Numerous studies in Drosophila and in mammalian tissue culture have led to the hypothesis that activators might regulate pausing of RNA polymerase II. For example, characterization of RNA polymerase occupancy of the Drosophila $h s p 70$ promoter demonstrated that a polymerase complex is paused proximal to the promoter prior to induction and that induction must cause some release of the pause (Rougvie and Lis 1988). Recently, it has been shown that activators or enhancers can decrease pausing on transfected or injected promoters (Yankulov et al. 1994; Krumm et al. 1995).

The data presented here demonstrate an effect of activators on pausing in vitro and imply that chromatin structure plays an important role in this regulation: $\mathrm{Nu}-$ cleosome formation creates an increased block to tran- 
scriptional elongation, and activation domains are able to suppress this block. Activators might relieve the block to elongation through interaction with the general transcription machinery, through a direct destabilization of nucleosomal structure in transcribed regions, or via both mechanisms. It has been proposed that promoterproximal pausing like that observed on $h s p 70$ is caused by contacts between the elongating RNA polymerase and general transcription factors that remain bound to the TATA box (Usheva et al. 1992; Lis and Wu 1993). It is possible that in the system described here, such contacts are necessary for pausing but that the additional constraint imposed by a nucleosome is also required. In this scenario, the effect of the activator on the contacts between the general transcription factors and RNA polymerase suffices to increase elongation; however, maximal effects on nucleosomal templates require additional activities that are present in the hSWI/SNF fractions. It is possible that these activities are simply facilitating activator occupancy, but we disfavor this possibility because vast excesses of activator cannot suppress the enhancement of elongation afforded by the hSWI/SNF fraction and because protein gels of washed templates show that saturating levels of activator are stably associated with the template (data not shown).

\section{A role for nucleosome-disrupting activities in regulation of pausing}

It was necessary to supplement our in vitro system with fractions that have hSWI/SNF activity to achieve maximal effects of the activator on elongation. These fractions have been shown previously to contain an ATPdependent nucleosome-disrupting activity (Imbalzano et al. 1994; Kwon et al. 1994). Whereas the effect of these fractions on elongation requires hydrolyzable ATP, and two separate highly enriched fractions (hSWI/SNF A and B) both enhance elongation, human SWI/SNF fractions are not homogeneous, so we cannot rigorously conclude that the nucleosome disruption activity itself is responsible for the effects on elongation. We can rule out the possibility that previously characterized elongation factors are responsible for the relief of pausing, though, because the effects of the hSWI/SNF fractions on elongation require hydrolyzable ATP (data not shown) and there is no effect of these fractions upon elongation on naked DNA (Fig. 7). Neither of these observations is true of known elongation factors. The hSWI/SNF fractions are not sufficient to increase elongation on nucleosomal templates because they have no effect in the absence of activator (Figs. 5 and 6).

These observations are complicated further by recent evidence suggesting that there are likely to be multiple complexes with ATP-dependent nucleosome disruption activity in the cell (Kwon et al. 1994; Tsukiyama et al. 1995). Our hSWI/SNF fractions contain some but not all of these complexes, so the work presented here is most simply interpreted as suggesting that some remodeling activity is important to facilitate relief of nucleosomedependent pausing. Moreover, the results above also ar- gue against a simple single-cause model for the regulation of promoter-proximal pausing. It is clear that nucleosomes are absolutely required to achieve pausing, yet chromatin-reorganizing factors alone are unable to release pausing; hence, activators probably do more than just recruit such factors. Transcriptional activators will release the pause, yet it does not appear that chromatinreorganizing factors are required to facilitate their occupancy under our assay conditions. It is most consistent with the data, therefore, to argue that activators and the activities present in the hSWI/SNF fraction are acting differently in a regulatory mechanism, but that both activities are necessary to achieve full release of pausing.

\section{Materials and methods}

\section{Templates for in vitro transcription}

All transcriptions were done using templates derived from the vectors pSAB8, pSABmix, pSAB12, or pML5-4NR. pSAB8 contains human $h s p 70$ sequences from -122 to +567 cloned HindIII-HindIII $(-122)$ and BglII-BamHI $(+567)$ into the pUC18 polylinker. Three $h s p 70$ point mutations were engineered by PCR to eliminate guanosine residues between +1 and +14 . (The modified sequence reads + 1-TAACTCCTATCCTG+14.) pSABmix is a mixture of plasmids identical to pSAB8, except that they contain modified hsp 70 sequences only to +335 , followed by zero, one, two, or three 20-bp linkers of sequence $5^{\prime}$-GATCTGGCGTAATTCGGGTT- ${ }^{\prime}$. pSAB12 is a pUC18-based vector that contains five GAL4 17-mer binding sites (Giniger et al. 1985) joined to the human $h s p 70$ gene from -35 to +567 . As in pSAB8, three $h s p 70$ point mutations were engineered by PCR to eliminate guanosine residues between +1 and +14 . pML5-4NR (Izban and Luse 1991) contains the adenovirus major late promoter from -171 to +37 fused to four 150-bp repeats from the bacterial chloramphenicol acetyltransferase (CAT) gene. (Again, point mutations have been engineered to eliminate all $G$ residues between +1 and +15 .) It was provided to us by Dr. Donal Luse (Cleveland Clinic Foundation Research Institute, $\mathrm{OH}$ ).

Prior to in vitro transcription, these plasmids were linearized, tethered to avidin-acrylic beads at an EcoRI site $2.6 \mathrm{~kb}$ upstream of the $h s p 70$ promoter, and cut at +445 (pSAB8, pSAB12) or $+335,+355,+375$, and +395 (pSABmix) or $+3.1 \mathrm{~kb}$ (pML5$4 \mathrm{NR}$ to produce templates for runoff transcripts of these lengths.

\section{In vitro transcription and nucleosome assembly}

To preform RNA polymerase ternary complexes and to endlabel the transcripts (Figs. 2-7), we used a protocol adapted from Izban and Luse (1991). We incubated $0.5 \mu \mathrm{g}$ of bead-bound template for $1 \mathrm{hr}$ at $30^{\circ} \mathrm{C}$ in a $25-\mu \mathrm{l}$ reaction, including $2 \mathrm{~mm} \mathrm{MgCl}_{2}$, $0.6 \mathrm{mM}$ ATP and CTP (Ultrapure; Pharmacia), $0.5 \mathrm{mM}$ $\left[\alpha^{-32}\right.$ P]UTP $(800 \mathrm{Ci} / \mathrm{mmole}$; New England Nuclear), 20 units of RNAsin (Promega), and $15 \mu$ l of total HeLa transcription factors and buffer D [Buffer D is $100 \mathrm{~mm} \mathrm{KCl,} \mathrm{20 \%} \mathrm{glycerol,} 20 \mathrm{mM}$ HEPES (pH 7.9), 0.2 mM EDTA, 0.5 mM DTT, 0.2 mM PMSF; factors included DE52-fractionated TFIIA and P11-fractionated other general transcription factors (Sumimoto et al. 1990). The amount of factors included in each reaction was empirically determined as that which gave maximal transcription on naked DNA. In Figures $2-4,3 \mu \mathrm{l}$ of a P11 $0.8 \mathrm{M}$ fraction and $2 \mu \mathrm{l}$ each of a P11 $0.5 \mathrm{M}$ fraction and DE52-fractionated TFIIA were used. In Figures 5-7, a different preparation of the same three frac- 
tions was used, in amounts of 4,3 , and $3 \mu \mathrm{l}$, respectively.] Templates were then pelleted and washed once with $50 \mu \mathrm{l}$ of $0.6 \times$ buffer $\mathrm{D}$ plus $1 \mathrm{mM} \mathrm{MgCl}_{2}$ and $1 \%$ Sarkosyl, and once with 50 $\mu l$ of $0.6 \times$ buffer $\mathrm{D}$ plus $2 \mathrm{~mm} \mathrm{MgCl}_{2}$.

To preform preinitiation complexes at +1 rather than elongation complexes at +15 (Fig. 4B), we incubated $0.5 \mu \mathrm{g}$ of beadbound template for $1 \mathrm{hr}$ at $30^{\circ} \mathrm{C}$ in a $25-\mu \mathrm{l}$ reaction including 2 $\mathrm{mM} \mathrm{MgCl}_{2}$ and $15 \mu \mathrm{l}$ of total HeLa transcription factors and buffer $\mathrm{D}$. Templates were then pelleted and washed twice with $50 \mu \mathrm{l}$ of $0.6 \times$ buffer $\mathrm{D}$ plus $2 \mathrm{~mm} \mathrm{MgCl}_{2}$. After nucleosome assembly (see below), the transcripts in these preinitiation complex reactions were endlabeled by incubating bead pellets for 1 $\mathrm{hr}$ at $30^{\circ} \mathrm{C}$ in a $25-\mu \mathrm{l}$ reaction including $2 \mathrm{mM} \mathrm{MgCl}_{2}, 0.6 \mathrm{~mm}$ ATP and CTP (Ultrapure; Pharmacia), 0.5 mM $\left[\alpha^{-32}\right.$ P]UTP (800 $\mathrm{Ci} / \mathrm{mmole}$; New England Nuclear), 20 units of RNAsin (Promega), and $15 \mu \mathrm{l}$ of buffer D. The reactions were then washed once with $50 \mu \mathrm{l}$ of $0.6 \times$ buffer D plus $2 \mathrm{mM} \mathrm{MgCl}_{2}$.

To assemble templates into nucleosome cores after stalling transcription complexes on them (Figs. 2-6), the washed reactions were resuspended in $25 \mu \mathrm{l}$ of buffer D plus $2 \mathrm{mM} \mathrm{MgCl}_{2}$ and 20 units of RNasin. To this, we added $50 \mu$ l of Xenopus laevis heat-treated assembly extract and $2 \mu \mathrm{g}$ of purified HeLa core histones (Workman et al. 1991a). The reactions were incubated for $1.5 \mathrm{hr}$ at $30^{\circ} \mathrm{C}$, then spun down, and washed with $50 \mu \mathrm{l}$ of $0.6 \times$ buffer $\mathrm{D}$ plus $2 \mathrm{mM} \mathrm{MgCl}_{2}$. [The heat-treated assembly extract (dHTE) used in this study was made as directed in Workman et al. (1991a) but was subsequently desalted over a P6DG column (Bio-Rad) to remove endogenous nucleotides. Extract was mixed with histones and preincubated at room temperature for $15 \mathrm{~min}$ prior to use in the reactions described above.]

To continue the elongation, either immediately after assembly (Figs. 2-6), after transcript endlabeling (in the case of reactions with a stalled preinitiation complex, Fig. 4B), or after restriction enzyme digestion (Fig. 3A; see method below), washed reactions were incubated for $1 \mathrm{hr}$ at $30^{\circ} \mathrm{C}$ in a $25-\mu \mathrm{l}$ reaction including $2 \mathrm{mM} \mathrm{MgCl} 2,0.6 \mathrm{mM} \mathrm{ATP}, \mathrm{CTP}, \mathrm{GTP}$, and UTP (Ultrapure; Pharmacia), 20 units of RNAsin (Promega), and $15 \mu \mathrm{l}$ of buffer $\mathrm{D}$ (modified to contain $250 \mathrm{~mm} \mathrm{KCl}$, so that the final $\mathrm{KCl}$ concentration was $150 \mathrm{~mm}$ to inhibit reinitiation). The reactions were stopped with $50 \mu$ l of stop solution $[67 \mathrm{mM} \mathrm{NaOAc}$ (pH 5), $6.7 \mathrm{~mm}$ EDTA, $0.33 \%$ SDS, $0.66 \mathrm{mg} / \mathrm{ml}$ of tRNA]. This basic protocol was modified slightly for reactions containing activators or hSWI/SNF fractions. The modifications are described later in this section.

Completed reactions were phenol-extracted, ethanol-precipitated, and analyzed on a $7.5 \%$ acrylamide $/ 7 \mathrm{M}$ urea $/ 1 \times \mathrm{TBE}$ sequencing gel. End-labeled marker DNA (labeled $M$ in figures) was either MspI-digested pBR322 DNA (New England Biolabs) or Boehringer Mannheim Marker V. Gels were exposed and quantitated on a Molecular Dynamics PhosphorImager.

\section{Restriction test for template assembly}

Transcription reactions were begun by transcription complex assembly followed by nucleosome assembly, exactly as described above. They were then resuspended in $25 \mu$ l of digestion buffer $\left(0.6 \times\right.$ buffer D with $\left.7 \mathrm{mM} \mathrm{MgCl}_{2}\right)$, and 20 units of the appropriate restriction enzyme (from New England Biolabs) was added. Reactions were digested for $2 \mathrm{hr}$ at $30^{\circ} \mathrm{C}$ and then washed once with $0.6 \times$ buffer D plus $1 \%$ Sarkosyl and $1 \mathrm{mM} \mathrm{MgCl}_{2}$ (a treatment that also strips nucleosomes) and once with $0.6 \times$ buffer D plus $2 \mathrm{mM} \mathrm{MgCl}$. Elongation was then continued, as above, and reactions were stopped and analyzed as described previously. (This digestion protocol was adapted from Morse 1989.)

\section{Activators and $h S W I / S N F$ in in vitro transcriptions}

The GAL4 DNA-binding domain (amino acids 1-94) was purified from E. coli as described in Chasman et al. (1989). It was 17 $\mu \mathrm{M}$ in concentration of dimer active for DNA binding, and $80 \%$ pure and $80 \%$ active relative to total protein. The GAL4-HSF protein contains amino acids $1-147$ of the GAL4 DNA-binding domain fused to amino acids 202-529 of human HSF1, which has been characterized in vivo as the regulatory and activation domains (Green et al. 1995; Zuo et al. 1995). It was expressed in E. coli as a $6 \times$ His-tagged fusion with the aid of the pRJR 1 expression vector (Reece et al. 1993) and purified over a nickelSepharose column (Qiagen) according to the manufacturer's directions. The resulting preparation was $4 \mu \mathrm{M}$ in concentration of active dimer, and was $30 \%$ pure and $90 \%$ active. Both proteins were dialyzed into buffer $D$.

Reactions containing GAL4 or GAL4-HSF (Figs. 5-7) were begun by prebinding the proteins to their cognate DNA sites: We incubated $0.5 \mu \mathrm{g}$ of bead-bound template for $15 \mathrm{~min}$ at room temperature in an $8-\mu \mathrm{l}$ reaction including $2 \mathrm{mM} \mathrm{MgCl}_{2}$ and a total of $5 \mu$ l of buffer D plus a 1.2 molar excess of activator relative to DNA-binding sites, or 1.4 pmole. This reaction was then increased to $25 \mu \mathrm{l}$ in volume by supplementing with 0.6 mM ATP and CTP (Ultrapure; Pharmacia), $0.5 \mathrm{~mm}\left[\alpha^{-32}\right.$ P]UTP (800 Ci/mmole; New England Nuclear), 20 units of RNAsin (Promega), and $10 \mu \mathrm{l}$ total of HeLa transcription factors and buffer $\mathrm{D}$, plus $\mathrm{MgCl}_{2}$ to maintain a concentration of $2 \mathrm{mM}$, and incubated for $\mathrm{l} \mathrm{hr}$ at $30^{\circ} \mathrm{C}$. Reactions were subsequently washed, assembled, and elongated as described above, but after each washing step reactions were supplemented with fresh protein at the same molar excess.

hSWI/SNF protein used in these studies (Figs. 5-7) was purified as described in Kwon et al. (1994) as far as the EconoQ column (Pharmacia), and dialyzed into buffer D. In these studies, it was added after assembly and prior to final elongation. Specifically, after nucleosome assembly and washing, transcription reactions were resuspended in a $23-\mu$ l reaction including 2 $\mathrm{mM} \mathrm{MgCl}_{2}, 4 \mathrm{mM}$ ATP, 20 units of RNAsin (Promega), and $15 \mu \mathrm{l}$ total of buffer $\mathrm{D}$ (modified to contain enough $\mathrm{KCl}$ that the concentration in the final reaction is $150 \mathrm{~mm}$ to inhibit reinitiation) plus the amount of hSWI/SNF fraction indicated in Figures 5-7. Reactions were then incubated for $20 \mathrm{~min}$ at $30^{\circ} \mathrm{C}$, whereupon they were supplemented with $2 \mu \mathrm{l}$ of the other three nucleotides (to $0.6 \mathrm{~mm}$ concentration). Subsequent transcriptional elongation and gel analysis of transcription products proceeded as described above.

\section{Permanganate footprinting}

Fifty milliliters of log-phase HeLa spinner cells were harvested, washed with PBS (pH 7.4), and resuspended in $1 \mathrm{ml}$ of PBS to a final concentration of $1 \times 10^{7}$ cells $/ \mathrm{ml}$. In experiments in which heat-shocked cells were examined, log-phase HeLa cells were incubated at $43^{\circ} \mathrm{C}$ for $1 \mathrm{hr}$. Cells were then washed with prewarmed PBS ( $\mathrm{pH} 7.4$ ), and resuspended at the same density. One-tenth volume of fresh $0.2 \mathrm{M} \mathrm{KMnO}_{4}$ was added, and reactions were incubated for $2 \mathrm{~min}$ at room temperature. Reactions were quenched with 1.5 volume of lysis solution $1100 \mathrm{mM} \mathrm{NaCl}$, $10 \mathrm{~mm}$ Tris at $\mathrm{pH} 7.8,25 \mathrm{~mm}$ EDTA, $0.5 \%$ SDS, $1 \mathrm{~m} \beta$-mercaptoethanol, $200 \mathrm{mg} / \mathrm{ml}$ of proteinase $\mathrm{K}$ ) and incubated for $4 \mathrm{hr}$ at $50^{\circ} \mathrm{C}$. They were then deproteinized by extraction once with equilibrated phenol, once with phenol/chloroform/isoamyl alcohol $(25: 24: 1)$ and once with chloroform, and $\mathrm{NaOAc}$ was added to a final concentration of $0.3 \mathrm{M}$.

Alternatively, genomic DNA (obtained by lysis and deproteinization as described in the previous paragraph, but without 
permanganate treatment) was resuspended at $1 \mathrm{mg} / \mathrm{ml}$. Onetenth volume of fresh $0.2 \mathrm{M} \mathrm{KMnO}_{4}$ was added, and the reaction was incubated for $2 \mathrm{~min}$ at room temperature. The reaction was quenched with 0.5 volume of DMS stop solution $(1.5 \mathrm{M} \mathrm{NaOAc}$ at $\mathrm{pH} 7,1 \mathrm{M} \beta$-mercaptoethanol).

In vivo and in vitro reactions were both precipitated once with ethanol, washed with $70 \%$ ethanol, and briefly dried. They were then resuspended in $0.3 \mathrm{ml}$ of $10 \%$ piperidine, incubated for $30 \mathrm{~min}$ at $90^{\circ} \mathrm{C}$, and lyophilized. Dried reactions were resuspended in $100 \mathrm{ml}$ of $\mathrm{H}_{2} \mathrm{O}$, and lyophilized twice more, and precipitated three times with $0.3 \mathrm{M} \mathrm{NaOAc}$ and 2.5 volumes of ethanol before a final resuspension in TE at $\sim 2 \mathrm{mg} / \mathrm{ml}$ of DNA.

Cleavages were visualized by LMPCR. LMPCR was performed according to the method of Mueller and Wold (1989), with $6 \mu \mathrm{g}$ of genomic DNA per LMPCR reaction. Primers used to visualize the coding strand were primer $1,24-\operatorname{mer} \mid+186$ to +163 relative to the start of transcription); primer $2,26-$ mer $(+154$ to +129$)$; primer $3,27-\operatorname{mer}(+147$ to +121$)$. Primers used to visualize the noncoding strand were primer 1,23 -mer $(-106$ to -84$)$; primer 2,28 -mer $(-73$ to -46$)$; primer 3,28 mer $(-65$ to -38$)$.

\section{Southern hybridization}

Nine plates of semiconfluent Hela cells were trypsinized from their plates, washed in PBS, and resuspended in $20 \mathrm{ml}$ of buffer L [5 mM PIPES (pH 8), $85 \mathrm{~mm} \mathrm{KCl,} 1 \mathrm{mM} \mathrm{CaCl}_{2}, 5 \%$ sucrose] with $0.5 \%$ NP-40, and incubated for 10 min on ice. Resultant nuclei were washed twice in detergent-free buffer $\mathrm{L}$, and then resuspended in $2 \mathrm{ml}$ of buffer $\mathrm{M}$ [15 mM Tris (pH 7.5), $15 \mathrm{mM}$ $\mathrm{NaCl}, 60 \mathrm{~mm} \mathrm{KCl}, 15 \mathrm{~mm}$ 2-mercaptoethanol, $1 \mathrm{mM} \mathrm{CaCl}_{2}, 3$ $\mathrm{mm} \mathrm{MgCl}, 0.34 \mathrm{M}$ sucrose]. Nuclei were adjusted to $1 \mathrm{mg} / \mathrm{ml}$ by monitoring 260-nm optical absorbance of a small amount diluted in $2 \mathrm{M} \mathrm{NaCl}$. Aliquots of nuclei $(0.4 \mathrm{ml})$ were briefly warmed to $30^{\circ} \mathrm{C}$ and treated with $30-600$ units of micrococcal nuclease (Sigma) for $3 \mathrm{~min}$. Reactions were then quenched with $1 \mathrm{ml}$ of stop buffer $(50 \mathrm{~mm}$ Tris at $\mathrm{pH} 7.5,150 \mathrm{~mm} \mathrm{NaCl}, 15 \mathrm{~mm}$ EDTA, $0.3 \%$ SDS) and treated for $1 \mathrm{hr}$ at $37^{\circ} \mathrm{C}$ with $50 \mu \mathrm{g}$ of RNase A (Sigma). Reactions were then extracted twice with equilibrated phenol, and precipitated twice with $0.3 \mathrm{M} \mathrm{NaOac}$ and ethanol.

Thirty micrograms of micrococcal nuclease-treated DNA was loaded into each lane of a $1.5 \%$ agarose gel. Marker lanes included $2 \mu \mathrm{g}$ of $M s p I$-digested pBR322 DNA from New England Biolabs. The gel was blotted to New England Nuclear Genescreen membrane according to the instructions of the manufacturer. Nucleic acids were cross-linked to the membrane with ultraviolet light using a Stratalinker (from Stratagene), also according to the manufacturer's directions.

The blot was probed with $\sim 10 \mathrm{ng}$ of BamHI-SacII hsp70 restriction fragment cut from pSAB8, following protocol I of the membrane manufacturer's instructions. (This probe has been shown previously to recognize a single band on blots of appropriately restriction-digested HeLa DNA.) The probe was labeled to a specific activity of $4 \times 10^{9} \mathrm{cpm} / \mu \mathrm{g}$ with a Boehringer Mannheim Random Priming Kit. The resultant labeled blot was exposed for 5 days on Kodak XAR film at $-70^{\circ} \mathrm{C}$ with an intensifying screen.

\section{Acknowledgments}

We are grateful to John Lis and colleagues for the body of work that led to these studies. In addition, we thank Dr. Donal Luse for the gift of plasmid pML5-4NR and Dr. Carolyn Kane for the gift of purified SII. HeLa cells used in the production of hSWI/
SNF and transcription factors were purchased from the $\mathrm{Na}$ tional Cell Culture Center in Minneapolis, MN. Our gratitude also goes to Elizabeth Newton, Dr. Jaya Yodh, and Dr. Marjorie Oettinger for critically reading this manuscript. This work was supported through grants from the National Institutes of Health and Hoechst AG (to R.E.K.), and by a grant from the U.S. Army Medical Research and Development Command (to A.N.I.).

The publication costs of this article were defrayed in part by payment of page charges. This article must therefore be hereby marked "advertisement" in accordance with 18 USC section 1734 solely to indicate this fact.

\section{References}

Arias, J.A. and W.S. Dynan. 1989. Promoter-dependent transcription by RNA polymerase II using immobilized enzyme complexes. J. Biol. Chem. 264: 3223-3229.

Cairns, B.R., Y.J. Kim, M.H. Sayer, B.C. Laurent, and R.D. Kornberg. 1994. A multisubunit complex containing the SWIl/ ADR6, SWI2/SNF2, SWI3, SNF5, and SNF6 gene products isolated from yeast. Proc. Natl. Acad. Sci. 91: 1950-1954.

Chasman, D.I., J. Leatherwood, M. Carey, M. Ptashne, and R.D. Kornberg. 1989. Activation of yeast polymerase II transcription by herpresvirus VP16 and GAL4 derivatives in vitro. Mol. Cell. Biol. 9: 4746-4749.

Clark, D.J. and G. Felsenfeld. 1992. A nucleosome core is transferred out of the path of a transcribing polymerase. Cell 71: 11-22.

Cote, J., J. Quinn, J.L. Workman, and C.L. Peterson. 1994. Stimulation of GAL4 derivative binding to nucleosomal DNA by the yeast SWI/SNF complex. Science 265: 53-60.

Croston, G.E., P.J. Laybourn, S.M. Paranjape, and J.T. Kadonaga. 1992. Mechanism of transcriptional antirepression by GAL4-VP16. Genes \& Dev. 6: 2270-2281.

Cullen, B.R. 1990. The HIV-1 Tat protein: An RNA sequencespecific processivity factor? Cell 63: 655-657.

Flores, O., E. Maldonado, and D. Reinberg. 1989. Factors involved in specific transcription by mammalian RNA polymerase II. J. Biol. Chem. 264: 8913-8921.

Giardina, C., M. Perez-Riba, and J.T. Lis. 1992. Promoter melting and TFIID complexes on Drosophila genes in vivo. Genes \& Dev. 6: 2190-2200.

Gilmour, D.S. and J.T. Lis. 1986. RNA polymerase II interacts with the promoter region of the noninduced hsp 70 gene in Drosophila melanogaster cells. Mol. Cell. Biol. 6: 39843989.

Giniger, E. and M. Ptashe. 1987. Transcription in yeast activated by a putative amphipathic alpha-helix linked to a DNA-binding unit. Nature 330: 670-672.

Green, M., T.J. Schuetz, E.K. Sullivan, and R.E. Kingston. 1995. A Heat-shock responsive domain of human HSF1 that regulates transcriptional activation domain function. Mol. Cell. Biol. 15: 3354-3362.

Imbalzano, A.N., H. Kwon, M.R. Green, and R.E. Kingston. 1994. Facilitated binding of TATA-binding protein to nucleosomal DNA. Nature 370: 481-485.

Izban, M.G. and D.S. Luse. 1991. Transcription on nucleosomal templates by RNA polymerase II in vitro: Inhibition of elongation with enhancement of sequence-specific pausing. Genes \& Dev. 5: 683-696.

Kainz, M. and J. Roberts. 1992. Structure of transcriptional elongation complexes in vivo. Science 255: 838-841.

Kingston, R.E. and M.R. Green. 1994. Modeling eukaryotic transcriptional activation. Curr. Biol. 4: 325-332.

Knezetic, J.A. and D.S. Luse. 1986. The presence of nucleosomes 
on a DNA template prevents initiation by RNA polymerase II in vitro. Cell 45: 95-104.

Krumm, A., T. Meulia, M. Brunvand, and M. Groudine. 1992. The block to transcriptional elongation within the human c-myc gene is determined in the promoter-proximal region. Genes \& Dev. 6: 2201-2213.

Krumm, A., L.B. Hickey, and M. Groudine. 1995. Promoterproximal pausing of RNA polymerase II defines a general rate-limiting step after transcription initiation. Genes \& Dev. 9: 559-572.

Kwon, H., A.N. Imbalzano, P.A. Khavarl, and R.E. Kingston. 1994. Nucleosome disruption and enhancement of activator binding by a human SWI/SNF complex. Nature 370: 477481.

Lee, H., K.W. Kraus, M.F. Wolfner, and J.T. Lis. 1992. DNA sequence requirements for generating paused polymerase at the start of hsp70. Genes \& Dev. 6: 284-295.

Lis, J. and C. Wu. 1993. Protein traffic on the heat shock promoter: Parking, stalling, and trucking along. Cell 74: 1-4.

Lorch, Y., J.W. LaPointe, and R.D. Kornberg. 1987. Nucleosomes inhibit the initiation of transcription but allow chain elongation with the displacement of histones. Cell 49: 203210.

Matsui, T. 1987. Transcription of the adenovirus 2 major late and peptide IX genes under conditions of in vitro chromatin assembly. Mol. Cell. Biol. 7: 1401-1408.

Morimoto, R.I. 1993. Cells in stress: transcriptional activation of heat shock genes. Science 259: 1409-1410.

Morse, R.H. 1989. Nucleosomes inhibit both transcriptional initiation and elongation by RNA polymerase III in vitro. EMBO I. 8: 2343-2351.

Mueller, P.R. and B. Wold. 1989. In vivo footprinting of a muscle-specific enhancer by ligation-mediated PCR. Science 246: 780-786.

O'Neill, T.E., M. Roberge, and E.M. Bradbury. 1992. Nucleosome arrays inhibit both initiation and elongation of transcripts by bacteriophage T7 RNA polymerase. /. Mol. Biol. 223: 67-78.

Ptashne, M. and A.F. Gann. 1990. Activators and targets. Nature 346: 329-331.

Rasmussen, E.B. and J.T. Lis. 1993. In vivo transcriptional pausing and cap formation on three Drosophila heat shock genes. Proc. Natl. Acad. Sci. 90: 7923-7927.

Reece, R.J., R.J. Rickles, and M. Ptashne. 1993. Overproduction and single-step purification of GAL4 fusion proteins from Escherichia coli. Gene 126: 105-107.

Reinberg, D. and R.G. Roeder. 1987. Factors involved in specific transcription by RNA polymerase II. I. Biol. Chem. 262: 3331-3337.

Reines, D., M.J. Chamberlin, and C.M. Kane. 1989. Transcription elongation factor SII (TFIIS) enables RNA polymerase II to elongate through a block to transcription in a human gene in vitro. I. Biol. Chem. 264: 10799-10809.

Rougvie, A.E. and J.T. Lis. 1988. The RNA polymerase II molecule at the $5^{\prime}$ end of the uninduced $h s p 70$ gene of $D$. melanogaster is transcriptionally engaged. Cell 54: 795-804.

- 1990. Postinitiation transcriptional control in Drosophila melanogaster. Mol. Cell. Biol. 10:604l-6045.

Sasse-Dwight, S. and J.D. Gralla. 1989. $\mathrm{KMnO}_{4}$ as a probe for lac promoter DNA melting and mechanism in vivo. J. Biol. Chem. 264: 8074-8081.

Schuetz, T.J., G.G. Gallo, L. Sheldon, P. Tempst, and R.E. Kingston. 1991. Isolation of a cDNA for HSF2: Evidence for two heat shock factor genes in humans. Proc. Natl. Acad. Sci. 88:691 1-6915.

Spencer, C.A. and M. Groudine. 1990. Transcription elongation and eukaryotic gene regulation. Oncogene 5: 777-785.

Studitsky, V.M., D.J. Clark, and G. Felsenfeld. 1994. A histone octamer can step around a transcribing polymerase without leaving the template. Cell 76: 371-382.

- 1995 . Overcoming a nucleosomal barrier to transcription. Cell 83: 19-27.

Sumimoto, H., Y. Ohkuma, T. Yamamoto, M. Horikoshi, and R.G. Roeder. 1990. Factors involved in specific transcription by RNA polymerase II: Identification of general transcription factor TFIIG. Proc. Nat1. Acad. Sci. 87: 9158-9162.

Tjian, R. and T. Maniatis. 1994. Transcriptional activation: a complex puzzle with few easy pieces. Cell 77: 5-8.

Tsukiyama, T. and C. Wu. 1995. Purification and properties of an ATP-dependent nucleosome remodeling factor. Cell 83: $1011-1020$.

Tsukiyama, T., C. Daniel, J. Tamkun, and C. Wu. 1995. ISWI, a member of the SWI2/SNF2 ATPase family, encodes the 140 $\mathrm{kDa}$ subunit of the nucleosome remodeling factor. Cell 83: 1021-1026.

Usheva, A., E. Maldonado, A. Goldring, H. Lu, C. Houbavi, D. Reinberg, and Y. Alyoni. 1992. Specific interaction between the nonphosphorylated form of RNA polymerase II and the TATA-binding protein. Cell 69: 871-881.

van Holde, K.E., D.E. Lohr, and C. Robert. 1992. What happens to nucleosomes during transcription? $/$. Biol. Chem. 267: 2837-2840.

Wang, W., M. Carey, and J.D. Gralla. 1992. Polymerase II promoter activation: Closed complex formation and ATPdriven start site melting. Science 255: 450-453.

Winston, F. and M. Carlson. 1992. Yeast SNF/SWI transcriptional activators and the SPT/SIN chromatin connection. Trends Genet. 8: 387-391.

Workman, J.L., and A.R. Buchman. 1993. Multiple functions of nucleosomes and regulatory factors in transcription. Trends Biochem. 18: 90-95.

Workman, J.L., I.C.A. Taylor, R.E. Kingston, and R.G. Roeder. 1991a. Control of Class II gene transcription during in vitro nucleosome assembly. Methods Cell Biol. 35: 419-447.

Workman, J.L., I.C.A. Taylor, and R.E. Kingston. 1991b. Activation domains of stably-bound GAL4 derivatives alleviate repression of promoters by nucleosomes. Cell 64: 533-544.

Yankulov, K., J. Blau, T. Purton, S. Roberts, and D.L. Bentley. 1994. Transcriptional elongation by RNA polymerase II is stimulated by transactivators. Cell 77: 749-759.

Zuo, J., D. Rungger, and R. Voellmy. 1995. Multiple layers of regulation of human heat shock transcription factor 1. Mol. Cell. Biol. 15: 4319-4330. 


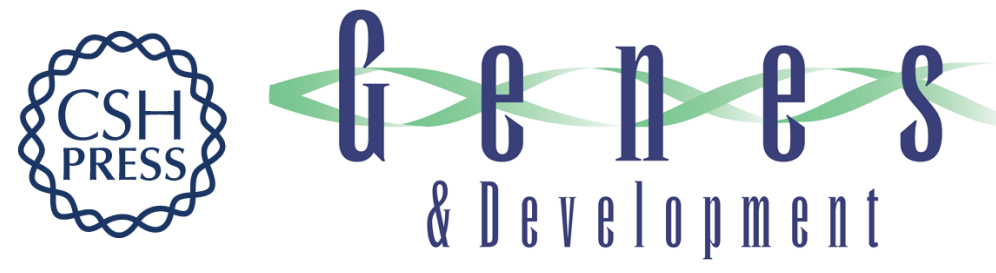

\section{Activator-dependent regulation of transcriptional pausing on nucleosomal templates.}

S A Brown, A N Imbalzano and R E Kingston

Genes Dev. 1996, 10:

Access the most recent version at doi:10.1101/gad.10.12.1479

References This article cites 53 articles, 27 of which can be accessed free at:

http://genesdev.cshlp.org/content/10/12/1479.full.html\#ref-list-1

License

Email Alerting

Service

Receive free email alerts when new articles cite this article - sign up in the box at the top right corner of the article or click here.

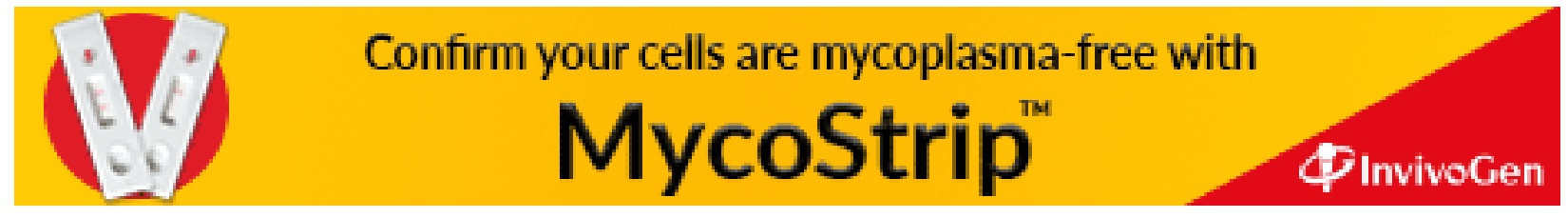

